\title{
Influence of Temperature and Host Plants on The Development of The Two-spotted Spider Mite, Tetranychus urticae Koch (Acari: Tetranychidae)
}

\author{
M. Z. Embarak, A. A. A. Salem and Aiman K. Abou El-Saad \\ Plant Protection Res. Institute, Agricultural Research Center, Giza, Egypt
}

\begin{abstract}
Duration of immature stages of the two-spotted spider mite, Tetranychus urticae Koch, reared on eggplant leaves at constant temperatures of 21,25 and $29^{\circ} \mathrm{C}$ was determined. Developmental threshold of the immature stages was $10.4^{\circ} \mathrm{C}$. The mean number of degree- days required by $T$. urticae to complete its development was $133.5 \mathrm{DD}$. The total mortality from egg to adult emergence was $32.14,26.8$ and $30.36 \%$ at 21,25 and $29^{\circ} \mathrm{C}$, respectively. Moreover, the greatest mortality occurred during the egg stage. Regarding host plant involved, T. urticae developed faster on peanut, Arachis hypogae L. (8.08 days), followed by cucumber, Cucumis sativus L. (9.31 days) and eggplant, Solanum melongena L. ( 9.37 days). These results indicated that the temperature and host plant affected the development time of $T$. urticae.
\end{abstract}

Key words: Tetranychus urticae; temperature; host plant; development.

\section{INTRODUCTION}

The two-spotted spider mite, Tetranychus urticae Koch (Acari: Tetranychidae) is one of the most serious pests on vegetables and crops in agriecosystem. Temperature is usually the environment factor with the greatest effect on development rate of mite stages. To quantify the effect of temperature on mite development, life stage of a species may be held at constant temperatures and the resultant development times can be used to estimate development rate curves (Southwood, 1978). From these development rate curves, models can be formulated to predict development time as a function of temperature. The models are useful in making pest management decisions, or to be used as components of more comprehensive models for the investigation of population dynamics.

Host plants of spider mites differ in the degree of food quality, which either depend on the level of primary plant metabolites, or on the quantity and nature of secondary metabolites (Rosenthal and Berenbaum, 1991). Many secondary metabolites found in plants have a responsibility in defense against herbivores, pests and pathogens. These compounds can perform as toxins, deterrents, digestibility reducers or act as precursors to physical defense systems (Bennett and Wallsgrove, 1994; Balkema-Boomstra et al., 2003).

Several studies have investigated the effects of temperature on development and reproduction of tetranychid mites on different host plants, such as T. urticae on cotton (Carey and Bradley, 1982), Tetranychus piercei McGregor on banana (Yueguan et al., 2002), Eutetranychus banksi (McGregor) on sweet orange (Badii et al., 2003), T. urticae on beans (Praslicka and Huszar, 2004), T. urticae on apple (Kasap, 2004), Tetranychus turkestani Ugarov and Nikolski on eggplant (Nemati et al., 2005), T. urticae on eggplant (Ju et al., 2008), Eutetranychus orientalis (Klein) on Siris (Imani et al., 2009), T. turkestani on cucumber (Karami Jamour, 2011), T. urticae on Pear (Abd El-Wahed and El-Halawany, 2012) and T. urticae on persimmon trees ( El-Halawany and Abd El-Wahed,2013). 
However, few attempts have been made to determine the developmental threshold and the thermal units needed for development of $T$. urticae on some host plants, particularly in Egypt. Hence, the goal of this study was to evaluate the developmental threshold and the thermal requirements of $T$. urticae as a key pest on eggplant and the suitability of the three economically important host plants (i.e. eggplant, cucumber and peanut) to this mite species.

\section{MATERIALS AND METHODS}

This study was conducted in the laboratory of plant protection research at Assiut Governorate during the year of 2014. Three host plants [eggplant, Solanum melongena L. (Solanaceae); cucumber, Cucumis sativus L. (Cucurbitaceae) and peanut, Arachis hypogae L. (Fabaceae)] were used to investigate the development time and some life table parameters. Adults of $T$. urticae were collected from leaves of each host plant using a fine camel hair brush, the stock population of the mite was established in the laboratory by placing the adult stages on discs of related plants in Petri dishes (80 $\mathrm{mm}$ in diameter) with wetted cotton wool fixed on a disc of plastic foam (Mannaa, 1988). Newly deposited eggs (less than 24 hrs) were transferred singly to the disc of fresh eggplant leaves $(20 \mathrm{~mm}$ in diameter) placed on a watersaturated cotton in a Petri dish. Fifty six of mite eggs (egg on each disc) were incubated at each tested temperature of $\left(21,25\right.$ and $\left.29^{\circ} \mathrm{C}\right)$ with a photoperiod of $16: 8$ (L:D) and $60 \pm 10 \mathrm{R} \mathrm{H}$ and observed daily until hatching. The newly-hatched larvae (< 12 hours-old) were reared in each experimental temperature and provided with clean eggplant leaves as a source of food until emergence of the adults.

The same above-mentioned procedures were conducted with the three host plants (eggplant, cucumber and peanut) at $25^{\circ} \mathrm{C}$ to assess development times of these eggs and other immature stages until reaching adulthood for each host plant.

Data obtained were statistically analyzed using analysis of variance and means were compared according to Duncan's Multiple Range test (Duncan, 1955). Obtained results of each immature stage of $T$. urticae were used to calculate the development threshold $\left(\mathrm{t}_{0}\right)$ according to linear regression model: $\mathrm{Y}=\mathrm{a}+\mathrm{bx}$, whereas, $(\mathrm{Y})$ is the rate of development (100/duration) at temperature $(X)^{\circ} \mathrm{C}$, a is the intercept on the $Y$ axis, $b$ is the regression coefficient and the lower development threshold $\left(\mathrm{t}_{0}\right)=-\mathrm{a} / \mathrm{b}$. On the other hand, thermal units (TU) required for the development of each mite stage were calculated according to Mangat (1977); thermal units (DD's)= T (t-to) where, Tdevelopment time, $\mathrm{t}$ - temperature in degree centigrade and $\mathrm{t}_{0}$ - lower development threshold.

Also, the obtained data were used to form a concise statement for every interval of age, the number of deaths $\left(d_{x}\right)$, the number of survivors at the beginning of the age class $X$ $\left(I_{X}\right)$, the rate of mortality $\left(q_{X}\right)$, the numbers living between the ages $X$ and $X+1$, which is the age structure $\left(L_{x}\right)$ and survival rate within stage $\left(S_{x}\right)$. 


\section{RESULTS AND DISCUSSION}

1. Development time of the immature stages:

The results in Table (1) show that the incubation period of $T$. urticae decreased as temperature increased. It averaged $5.59 \pm 0.74 ; 3.94 \pm 0.34$ and $2.59 \pm 0.25$ days at 21,25 and $29^{\circ} \mathrm{C}$, respectively. The duration of larval, protonymph and deutonymph stages decreased gradually as temperature increased from 21 to $29^{\circ} \mathrm{C}$. The larval stage durated $2.37 \pm 0.1 ; 1.85 \pm 0.05$ and $1.18 \pm 0.12$ days at 21,25 and $29^{\circ} \mathrm{C}$, successively. The periods of protonymph and deutonymph stages lasted for $2.40 \pm 0.18$ and $2.24 \pm 0.09 ; 1.67 \pm 0.18$ and $1.91 \pm 0.21 ; 1.75 \pm 0.03$ and $1.68 \pm 0.04$ days at the same degrees of temperature, respectively.

Statistical analysis of data showed significant variation between the development periods of each immature stage of two-spotted spider mite at all tested temperatures. In addition, when the total development time (from egg to adult emergence) is compared among all tested temperatures, the variation is significant.

Table (1): development periods (in days) of the immature stages of $T$. urticae, reared at different constant temperatures

\begin{tabular}{cccccc}
\hline & \multicolumn{5}{c}{ Development periods (in days) \pm SD } \\
\cline { 2 - 6 } Temp. $\left({ }^{\circ} \mathbf{C}\right)$ & Egg & Larva & Protonymph & Deutoymph & $\begin{array}{c}\text { (from egg to adult } \\
\text { emergence) }\end{array}$ \\
\hline & & & & $2.24 \pm 0.09 \mathrm{a}$ & $12.60 \pm 0.72 \mathrm{a}$ \\
21 & $5.59 \pm 0.74 \mathrm{a}$ & $2.37 \pm 0.1 \mathrm{a}$ & $2.40 \pm 0.18 \mathrm{a}$ & $2.37 \pm 0.1 \mathrm{~b}$ \\
29 & $3.94 \pm 0.34 \mathrm{~b}$ & $1.85 \pm 0.05 \mathrm{~b}$ & $1.67 \pm 0.18 \mathrm{~b}$ & $1.91 \pm 0.21 \mathrm{ab}$ & 9.30 \\
& $2.59 \pm 0.25 \mathrm{c}$ & $1.18 \pm 0.12 \mathrm{c}$ & $1.75 \pm 0.03 \mathrm{~b}$ & $1.68 \pm 0.04 \mathrm{~b}$ & $7.20 \pm 0.19 \mathrm{c}$
\end{tabular}

${ }^{\star}$ Mean in each column, followed by the same letter are not significantly different at 0.05 probability level

Data in Table (1) gave the possibility of calculating the developmental threshold $\left(\mathrm{t}_{0}\right)$ and the thermal units (TUs) required for the development of the immature stages of the mite according to Mangat (1977). Hypothetical temperature threshold which was used in the estimation of $\left(\mathrm{t}_{0}\right)$ and (TUs) were chosen below the rearing temperatures of 21 and $29^{\circ} \mathrm{C}$, Table (2). Data revealed that the threshold temperature for development of the immature stages of the mite on eggplant, as shown in Figure (1), was $10.4^{\circ} \mathrm{C}$ and the thermal units necessary to complete its development were about 133.5 day-degrees. 
Table (2): Day-degrees (DD) necessary for the development of immature stages to adult stage of $T$. urticae using hypothetical temperature thresholds below rearing temperatures of 21 and $29^{\circ} \mathrm{C}$

\begin{tabular}{ccc}
\hline \multirow{2}{*}{ Temp. threshold $\left(\mathbf{t}_{\mathbf{0}}\right)$} & \multicolumn{2}{c}{ Thermal units (DD's) $\mathbf{=} \mathbf{T}\left(\mathbf{t}-\mathbf{t}_{\mathbf{0}}\right)$} \\
\cline { 2 - 3 } $\mathbf{2}$ & $\mathbf{2 1}^{\circ} \mathbf{C}(\mathbf{T}=\mathbf{1 2 . 6})$ & 158.4 \\
$\mathbf{2 9} \mathbf{9}^{\circ} \mathbf{C}(\mathbf{T}=\mathbf{7 . 2 0})$ \\
\hline 9 & 176.4 & 151.2 \\
10 & 163.8 & 144.0 \\
11 & 151.2 & 136.8 \\
12 & 138.6 & 129.6 \\
13 & 126.0 & 122.4 \\
14 & 113.4 & 115.2 \\
15 & 100.8 & 108.0 \\
16 & 88.2 & 100.8 \\
17 & 75.6 & 93.6 \\
18 & 63.0 & 86.4 \\
19 & 50.4 & 79.2 \\
20 & 37.8 & 72.0 \\
\hline
\end{tabular}

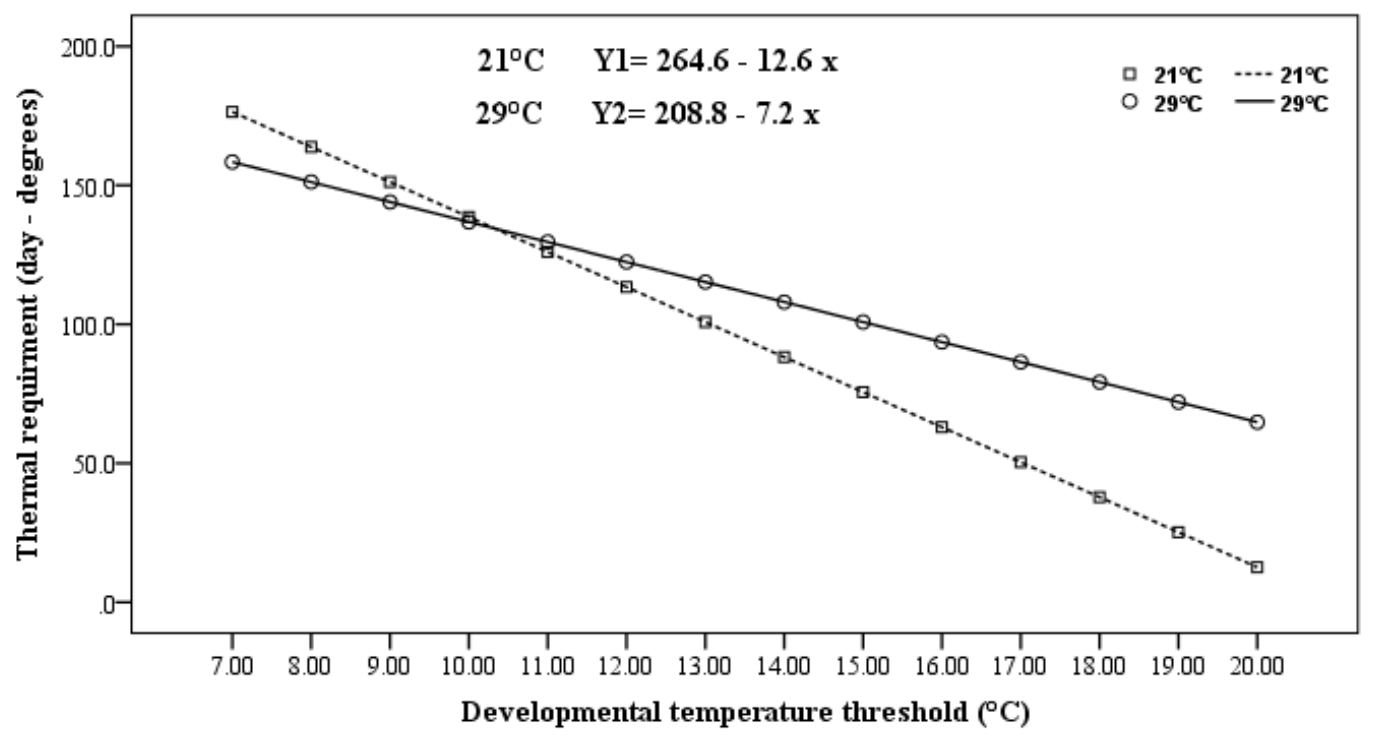

Fig. (1): Thermal units needed for the development of the immature stages of $T$. urticae.

\section{Age-specific survival life table:}

Data in Table (3) referred to the combined life table describing one pathway for age specific mortality of $T$. urticae immature stages reared at the three constant temperatures. Results indicated that the highest percentage $(73.2 \%)$ of 56 two-spotted spider mite eggs successfully emerged as adults occurred at $25^{\circ} \mathrm{C}$ followed by $(69.64 \%)$ at $29^{\circ} \mathrm{C}$, while the lowest percentage 
$(67.86 \%)$ of adults emerged from the mite eggs was recorded at $21^{\circ} \mathrm{C}$. Moreover, the life table of $T$. urticae indicated high mortality occurring during the early life stages against a distinct lower percentage of mortality as they reached adulthood.

Table (3): Life table of two spotted spider mite, $T$. urticae reared on eggplant leaves at different constant temperatures

\begin{tabular}{ccccccc}
\hline Temp. $\left({ }^{\circ} \mathbf{C}\right)$ & $\mathbf{X}$ & $\mathbf{I X}$ & $\mathbf{L x}$ & $\mathbf{d x}$ & $\mathbf{1 0 0 \mathbf { q }}$ & $\mathbf{S x}$ \\
\hline \multirow{3}{*}{21} & Eggs & 56 & 48 & 15 & 26.79 & 73.21 \\
& Larva & 41 & 40 & 2 & 4.88 & 95.12 \\
& Protoymph & 39 & 38 & 1 & 2.56 & 97.44 \\
& Deutonymph & 38 & 38 & 0 & 0.0 & 100.0 \\
& Adult & 38 & 19 & - & - & - \\
\hline \multirow{3}{*}{25} & Eggs & 56 & 52 & 7 & 12.50 & 87.50 \\
& Larva & 49 & 47 & 4 & 8.16 & 91.84 \\
& Protoymph & 45 & 43 & 3 & 6.67 & 93.33 \\
& Deutonymph & 42 & 41 & 1 & 2.38 & 97.62 \\
& Adult & 41 & 20 & - & - & - \\
\hline \multirow{2}{*}{29} & Eggs & 56 & 50 & 12 & 21.43 & 78.57 \\
& Larva & 44 & 43 & 2 & 4.55 & 95.45 \\
& Protoymph & 42 & 41 & 2 & 4.76 & 95.24 \\
& Deutonymph & 40 & 39 & 1 & 2.5 & 97.5 \\
& Adult & 39 & 19 & - & - & - \\
\hline
\end{tabular}

$\mathbf{X}=$ development stage

$\mathbf{I x}=$ number entering stage

$\mathbf{L x}=$ number alive between stage $\mathrm{X}$ and $\mathrm{X}+1$

$\mathbf{d x}=$ number that died in stage $\mathrm{X}$

$100 q \mathbf{x}=$ percent apparent mortality

Sx $=$ survival rate within stage

\section{Influence of host plant on the development time of T. urticae:}

Obtained results in Table (4) elucidated insignificant variation between the two host plants, eggplant and cucumber in case of the total development period of $T$. urticae, whereas significant variation between peanut and each of eggplant and cucumber for the total development period $(F=18.28 ; d f=2$; $p=0.00001$ ). The development period of different stages of $T$. urticae indicated that larval stage development occupied the first rank ( $1.51 \pm 0.41$ days) followed by $(1.72 \pm 0.11,1.82 \pm 0.13$ and $3.87 \pm 0.46$ days) for protonymph, deutonymph and egg stages, subsequently with significant differences $(F=1272.03 ; d f=4$; $p=0.00001$ ). 
Table (4): Length of the development period of $T$. urticae as influenced by host plant (in days) at constant temperature of $25^{\circ} \mathrm{C}$

\begin{tabular}{lccccc}
\hline \multirow{2}{*}{ Hosts } & \multicolumn{5}{c}{ Developmental periods (in days) } \\
\cline { 2 - 5 } & Egg & Larva & Nymph & $\begin{array}{c}\text { Total (from egg to } \\
\text { adult emergence) }\end{array}$ & \\
\hline Eggplant & $3.94 \mathrm{Ab}^{*}$ & $1.85 \mathrm{Ad}$ & $3.58 \mathrm{Ac}$ & $9.37 \mathrm{Aa}$ & $4.69 \mathrm{~A}$ \\
Cucumber & $4.31 \mathrm{Ab}$ & $1.52 \mathrm{Ad}$ & $3.48 \mathrm{Ac}$ & $9.31 \mathrm{Aa}$ & $4.65 \mathrm{~A}$ \\
Peanut & $3.35 \mathrm{Bc}$ & $1.17 \mathrm{Ad}$ & $3.56 \mathrm{Ab}$ & $8.08 \mathrm{Ba}$ & $4.04 \mathrm{~B}$ \\
Average & $3.87 \mathrm{~b}$ & $1.51 \mathrm{~d}$ & $3.54 \mathrm{c}$ & $8.92 \mathrm{a}$ & \\
\hline detectable differences are indicated by capital letters in host plants within each column \\
and lower case in stages within each row.
\end{tabular}

Voluminous of studies are available on the biology of $T$. urticae on different host plants. However, it would be uphill to compare the present results with others, as rearing conditions (temperature as well as host plant) were different. As a discussion, the results of the present study clearly showed the effect of temperature and host plants on development time and mortality of immature stages were in agreement with previous results have been reported by many authors. Immature development times of $T$. urticae were 12.60, 9.37 and 7.20 days at 21,25 and $29^{\circ} \mathrm{C}$, respectively. Praslicka and Huszar (2004) found that the length of development times of $T$. urticae on Capsicum annuum L. were $12.9,10.10$ and 7.0 days at 20,25 and $30^{\circ} \mathrm{C}$. While, Nemati et al. (2005) observed the developmental times of $T$. turkestani on eggplant were $30.32,17.41,9.98$ and 5.71 days at $15,20,25$ and $30^{\circ} \mathrm{C}$, respectively. Whereas, Ju et al. (2008) reported $\left(25.8\right.$ days at $\left.17^{\circ} \mathrm{C}\right)$ for $T$. urticae on eggplant. Romeih et al. (2013) also, reported that the total development time of $T$. urticae males was significantly influenced by the rose cultivars and ranged between 12.01 and 7.88 at $20^{\circ} \mathrm{C} ; 6.84$ and 3.44 at $25^{\circ} \mathrm{C}$; and 5.35 and 2.57 days at $30^{\circ} \mathrm{C}$. Moreover, our findings at $25^{\circ} \mathrm{C}$ are close to those recorded on different host plants by (Skirvin and Williams, 1999) 11.7 days; (Kasap, 2004) 10.0 and 9.3 days; (Rajakumar et al., 2005) 12.36 and 10.7 days for female and male, respectively, and (Razmjou et al., 2009) 9.38 days.

The lower temperature threshold of $10.4^{\circ} \mathrm{C}$ for $T$. urticae, computed by linear regression, is similar to the $10.57^{\circ} \mathrm{C}$ reported by Ali (2002) on cotton, but this value was lower than those reported by Ju et al. (2008) for T. urticae (12.8 and $12.5^{\circ} \mathrm{C}$ ) for male and female on eggplant and by Nemati et al. (2005) for female T. turkestani $\left(13.4^{\circ} \mathrm{C}\right)$ on eggplant, as well as Riahi et al. (2013) for $T$. urticae $\left(12.1\right.$ and $\left.13.8^{\circ} \mathrm{C}\right)$ for male and female on peach. While, the value of temperature threshold is higher than the $8.4^{\circ} \mathrm{C}$ reported by Kasap (2004) on apple.

The mean number of degree-days required by $T$. urticae to complete its development was 133.5DD, which was closer to 140.33 and 131.88DD for female and male, respectively, required by $T$. turkestani to complete its development (Jamour and Shishehbor, 2012) and was higher than those of Ju et al. (2008) 
on eggplant (80.5 and 74.7DD) for female and male, respectively; and Nemati et al. (2005) for female T. turkestani (102.0DD) on eggplant. While, these was lower than those of (160.2 and 174DD) for females and males of T. urticae (Riahi et al., 2013); (172.4DD) reported for female (Najafabadi and Zamani, 2013). on apple by Kasap (2004) and (155DD) estimated by Ali (2002) on cotton. The total mortality from egg to adult emergence was $32.14,26.8$ and $30.36 \%$ at 21,25 and $29^{\circ} \mathrm{C}$, respectively. Similar results have been stated by (Riahi et al., 2011) 27.45 to $68.5 \%$ of eggs developed to maturity on peach, whereas Saeidi (2011) mentioned that $74-88 \%$ of eggs completed its maturity. Immature stages mortality rate ranged also from 11.65 to $18.75 \%$ on different bean cultivars (Najafabadi and Zamani, 2013). In addition, among immature stages, the greatest mortality occurred during the egg stage was in accordance with the results of (Najafabadi and Zamani, 2013).

The difference among the three host plants; eggplant, cucumber and peanut was further confirmed by the statistical analysis. Therefore, obtained results from these experiments showed a better performance of $T$. urticae on peanut leaf discs than cucumber and eggplant. This was shown in the development times of $T$. urticae (8.08, 9.31 and 9.37days) for peanut, cucumber and eggplant, in respect. Similar results have been also observed on various host plants (Praslicka and Huszar, 2004 and Razmjou et al., 2009). The difference in the development of the mite on different hosts may have been caused by quality, accessibility or actual ratio of nutrients, as indicated by Wermelinger et al. (1985). In addition, variations among the other aspects and parameters included in this article might be due to the differences to either the mite species or to the adopted techniques.

\section{REFERENCES}

Abd El-Wahed, N. M. and A. S. El-Halawany. 2012. Effect of Temperature Degrees on the Biology and Life Table Parameters of Tetranychus urticae Koch on Two Pear varieties. Egypt. Acad. J. Biolog. Sci., 4(1): 103-109.

Ali, A. G. 2002. development of the two-spotted spider mite, Tetranychus urticae koch (Acari: Tetranychidae) under certain constant temperature. Assiut J. Agric. Sci., 33(5): 29-37.

Badii, M. H., S. Varela, A. Flores and J. Landeros. 2003.Temperature-based Life History and Life Table Parameters of Texas Citrus Mite on Orange (Acari: Tetranychidae). Sys. Appl. Acarol, 8: 25-38.

Balkema-Boomstra, A. G., S. Zijlstra, F. W. A. Verstappen, H. Inggamer, P. E. Mercke, M. A. Jongsma and H. J. Bouwmeester. 2003. Role of cucurbitacin $\mathrm{C}$ in resistance to spider mite (Tetranychus urticae) in cucumber (Cucumis sativus L.). Journal of Chemical Ecology, 29: 225235.

Bennett, R. N. and R. M. Wallsgrove. 1994. Secondary metabolites in plant defense mechanisms. New Phytologist, 127: 617-633.

Carey, J. R. and J. W. Bradley. 1982. Developmental Rates, Vital Schedules, Sex Ratios, and Life Tables for Teranychus urticae, Tetranychus 
turkestani and Tetranychu pacificus (Acarina: Tetranychidae) on Cotton. Acarologia, 23(4): 333-345.

Duncan, D. B. 1955. Multiple range and multiple F-test. Biometrics, 11: 1-42.

El-Halawany, A. S.and N. M. Abd El-Wahed. 2013. Effect of temperature and host plant on dvelopmental times and life table parameters of Tetranychus urticae Koch on persimmon trees. (Acari: Tetranychidae). Egypt. J. Agric. Res., 91 (2):995-607.

Imani, Z., P. Shishehbor and F. Sohrabi. 2009. Effect of Temperature on Life History and Life Table of Eutetranychus orientalis (Klein) (Acari: Tetranychidae). Sys. Appl. Acarol., 14: 11-18.

Jamour, T. K. and P. Shishehbor. 2012. Development and life table parameters of Tetranychus turkestani (Acarina: Tetranychidae) at different constant temperatures. Acarologia, 52(2): 113-122.

Ju, K., L. Sangkoo, K. JeongMan, K. YoungRip, K. TaeHeung and K. Jisoo. 2008. Effect of Temperature on Development and Life Table Parameters of Tetranychus urticae Koch (Acari: Tetranychide) Reared on Eggplants. Kor. J. Appl. Entomol., 47(2): 163-168.

Karami-Jamour, T. 2011. Biology of Two Spotted Spider Mite, Tetranychus turkestani Ugarov and Nikolski and Its Predator, Stethorus gilvifrons Mulsant under Laboratory Conditions. MSc. Thesis, University of Shahid Chamran, Ahvaz, Iran, 138 PP.

Kasap, I. 2004. Effect of Apple Cultivar and of Temperature on the Biology and Life Table Parameters of The Two-spotted Spider Mite, Tetranychus urticae. Phytoparasitica, 32(1): 73-82.

Mangat, B. S. 1977. Thermal threshold and temperature accumulation for the cotton bollworm. J. Tennessee Academy Sci., 55:15-16.

Mannaa, S. H. 1988. Biological and ecological studies on certain pests of fig with special reference to their integrated pest management. Ph. D. Thesis, Fac. Agric., Assiut Univ., Assuit, Egypt.

Najafabadi, S. S. M. and A. A. Zamani. 2013. The effect of common bean cultivars on life table parameters of Tetranychus urticae (Acari: Tetranychidae). Persian Journal of Acarology, 2(2): 297-310.

Nemati, A. R., A. Soleimannejadian, P. Shishehbor and K. Kamali. 2005. Evaluation of the Effect of Temperature on Biological Parameters of Tetranychus turkestani Ugarov and Nikolski (Acari: Tetranychidae). Sci. J. Agric., 28: 209- 222.

Praslicka, J. and J. Huszar . 2004. Influence of Temperature and Host Plants on the Developmental and Fecundity of the Spider Mite (Tetranychus urticae). Plant Prot. Sci., 40(4): 141-144.

Rajakumar, E., P. S. Hugar and B. V. Patil. 2005. Biology of red spider mite, Tetranychus urticae koch (Acari: Tetranychidae) on jasmine. J. Agric. Sci., 18(1): 147-149.

Razmjou, J., H. Tavakkoli and M. Nemati. 2009. Life history traits of Tetranychus urticae on three legumes (Acari: Tetanychidae). Munis Entomol. Zool., 4(1): 204-211. 
Riahi, E., A. Nemati, P. Shishehbor and Z. Saeidi. 2011. Population growth parameters of the two-spotted spider mite, Tetranychus urticae, on three peach varieties in Iran. Acarologia 51(4): 473-480.

Riahi, E. , P. Shishehbor, A. R. Nemati and Z. Saeidi. 2013. Temperature effects on development and life table parameters of Tetranychus urticae (Acari: Tetranychidae). J. Agr. Sci. Tech., 15: 661-672.

Romeih, A. H. M., R. I. A. Abo-Shnaf and M. A. Rizk. 2013. Influence of rose cultivar conditions on reproduction of two-spotted spider mite. Life Science Journal, 10(3): 1334-1339.

Rosenthal, G. A. and M. R. Berenbaum. 1991. Herbivores: Their Interaction with Secondary Plant Metabolites. vol. 2, Ecological and Evolutionary Processes. London: Academic Press.

Saeidi, Z. 2011. Study on resistance of almond cultivars to spider mites-Iran: Chaharmahal \& Bakhtiari Agricultural and Natural Resources Research Center. No. 86004. pp. 15.

Skirvin, D. J. and M. C. Williams. 1999. Differential effects of host plant species on a mite pest (Tetranychus urticae) and its predator (Phytoseiulus persimilis). Implication for Biological Control. Exp. Appl. Acarol., 23: 479- 512.

Southwood, T. R. E. 1978. Ecological Methods. Chapman and Hall, London, UK,232 PP.

Wermelinger, B., J. J. Oertli and V. Delucchi. 1985. Effect of host plant nitrogen fertilization on the biology of the two-spotted spider mite, Tetranychus urticae (Koch). Entomol. Exp. Appl., 38: 23-28.

Yueguan, F., Z. Faugping, P. Zhengqiang, L. Kui and J. Qian. 2002. The Effects of Temperature on the Development and Reproduction of Tetranychus piercei McGregor (Acari: Tetranychidae) in Banana. Sys. Appl. Acarol., 7: 69-76. 


\section{الملخص العربى}

\section{تأثثير الحرارة والعوائل النباتية على تطور أكاروس العنكبوت ذو البقعتين}

\section{ماجد زاهي إمبارك ، علاء الدين عبد القادر أحمد ، أيمن كامل أبو السعد}

معهد بحوث وقاية النباتات- مركز البحوث الزراعية- الجيزة- جمهورية مصر العربية

أجريت هذه الدراسة بهدف معرفة تأثير درجات الحرارة الثابتة على تطور آكاروس العنكبوت ذو البقعتين Tetranychus urticae

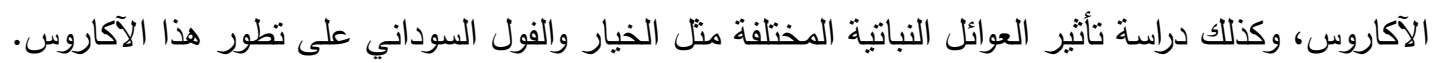
وقد أوضحت النتائج انه عند تربية الآكاروس على أوراق الباذنجان واستخدام درجات حرارة 21 ، 25 ، 29 م فأن فترة تطور الآكاروس تقل مع زيادة درجة الحرارة (12.60، 9.37، أيضا أن عنبة النمو للأطوار الغير كاملة كانت 10.4 درجة مئوية ، كما أن آكاروس العنكبوت ذورة دورة البقعنين يحتاج 133.5

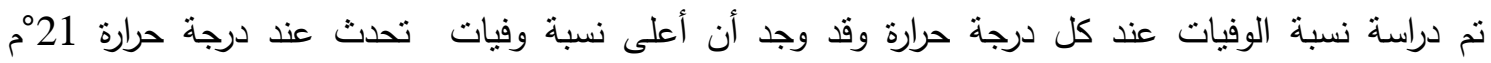

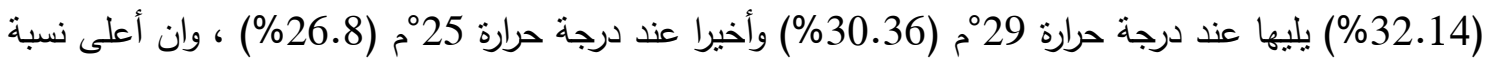
وفيات تحدث في طور البيضة عند درجات الحرارة المختلفة.

عند دراسة تأثير اختلاف العوائل النباتية على نطور آكاروس العنكبوت ذو البقعتين عند تربيته على درجة حرارة 250 م ، وجد أن الفول السوداني هو أفضل عائل لتطور آكاروس العنكبوت ذو البقعتين يليه الخبار وأخيرا الباذنجان، ويتضح ذلك من خلال طول فترة التطور حيث سجلت أقل فترة تطور على الفول السوداني ثم الخيار

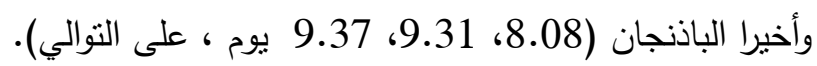

